\title{
L1CAM wt Allele
}

National Cancer Institute

\section{Source}

National Cancer Institute. L1CAM wt Allele. NCI Thesaurus. Code C112137.

Human L1CAM wild-type allele is located in the vicinity of Xq28 and is approximately $48 \mathrm{~kb}$ in length. This allele, which encodes neural cell adhesion molecule L1 protein, is involved in neuron-neuron cell adhesion, axon guidance and bundling of neurons. Mutation of the gene is associated with hydrocephalus due to stenosis of the aqueduct of Sylvius (HSAS), mental retardation, aphasia, shuffling gait, and adducted thumbs syndrome (MASA or CRASH syndrome), spastic paraplegia 1, X-linked and agenesis of the corpus callosum, Xlinked, partial and may contribute to intestinal ag ang lionosis in Hirschsprung disease. 